\title{
Studies of Seeding Millet in Accurate Grooves and Holes Under Water-Permeability Plastic Film
}

\author{
Jianmin Yao ${ }^{1}$, Wengang $\mathrm{Li}^{1}$, Ruiping Yang ${ }^{1}$, Yichao Wei ${ }^{1} \&$ Wanrong $\mathrm{Shi}^{2}$ \\ ${ }^{1}$ Agricultural Resources and Economics Institute of Shanxi Academy of Agricultural Sciences, Taiyuan, China \\ ${ }^{2}$ Agricultural Committee of Shenchi County of Shanxi Province, Xinzhou, China \\ Correspondence: Wengang Li, Agricultural Resources and Economics Institute of Shanxi Academy of \\ Agricultural Sciences, No. 4 WuCheng Road, Taiyuan, 030006, China. Tel: 86-134-5314-5623. E-mail: \\ lwg992003@qq.com
}

Received: March 28, 2014 Accepted: May 4, 2014 Online Published: June 15, 2014

doi:10.5539/jas.v6n7p276 URL: http://dx.doi.org/10.5539/jas.v6n7p276

\begin{abstract}
Because seeding techniques about ordinary plastic film in dry lands are of their respective defects including flat plastic film and mounds film, increased outputs of foxtail millet are limited. For this reason on the basis of composite techniques including wavy water-permeability plastic film of $1650 \mathrm{~mm}$ width and the film planter of 2MB-1/4 type, contrastive experiments are carried out in the dry flat area of sandy loam of HongAiZi village in Shenchi County of Shanxi Province during two years, whose characters are $39^{\circ} 30^{\prime} \mathrm{N}$ and $1400 \mathrm{~m}$ altitude for the situation, $125 \mathrm{~d}$ for the frost-free period, $2800 \mathrm{~h}$ for the annual sunshine duration and $450 \mathrm{~mm}$ for the annual precipitation. As a result millet outputs are improved efficiently and reach to $8840.33-9745.07 \mathrm{~kg} \cdot \mathrm{hm}^{-2}$, whose additional percentage is 101.24\%-118.44\%. After relative physical, chemical and biological indexes are investigated, measured and analyzed, main reasons of abundant outputs because of this technology are obtained, which are additions of cumulative soil temperatures, high utilization ratios of soil moisture and fertilizer, superiorities of microbial environments, rationalities of millet group structures, high emergence ratios of millet seedlings and so on.
\end{abstract}

Keywords: millet, water-permeability plastic film, contrastive experiments, outputs, film planter

\section{Introduction}

Foxtail millet originated in China 8000 years ago and is a kind of crop of abundant and high nutrition (Joshi, Sainani, Bastawade, \& Gupta, 1998; Ravindran, 1991; Yang, Tian, Lu, Yang, \& Ding, 2010). The cultivation period of foxtail millet reaches to more than 5000 years in Shanxi province (Gu, Ma, Gu, Du, \& Sun, 2004), and Shanxi is the largest province of planting spring foxtail millet (Tian, Wang, Li, Liu, \& Liu, 2013; Yang, Shi, \& Wang, 2006) in China. However, planting acreages shrank and outputs decreased by degrees from the early 1980s to the middle 1990s (Ma, Wang, \& Wang, 1998). Planting acreages shrank from $54.30 \times 10^{4} \mathrm{hm}^{2} \cdot \mathrm{a}^{-1}$ to $29.87 \times 10^{4}$ $\mathrm{hm}^{2} \cdot \mathrm{a}^{-1}$, total outputs decreased from $119.62 \times 10^{4} \mathrm{t} \cdot \mathrm{a}^{-1}$ to $59.30 \times 10^{4} \mathrm{t} \cdot \mathrm{a}^{-1}$ and single outputs decreased from 2205.00 $\mathrm{kg} \cdot \mathrm{hm}^{-2}$ to $1986.00 \mathrm{~kg} \cdot \mathrm{hm}^{-2}$ between 1982 and 1995 . Owing to declining outputs of foxtail millet, the technology named seeding foxtail millet in holes under ordinary plastic film (Guo \& Gu, 2000; Jiang, Wang, \& Jia, 1999; Zhao, Huang, \& Li, 1998; Zhu, Chen, \& Ren, 1998) was invented and applied, and outputs were improved to a certain extent. However, this technology has four defects: firstly, row spaces of seeding foxtail millet become too great because of the limit of the wheel-base parameter; secondly, emergence ratios of millet seedlings are small because mulching film and punching can't reach goals of seeding according to soil moisture; thirdly, controlling accurate quantities of seeding is not easy without a good separating device of seeds; fourthly, because soil covered on seedling holes is easy to become hard after raining, emergence ratios of millet seedlings are small. These problems can be solved through inventing and applying a new technique named seeding foxtail millet in accurate grooves and holes under wide and wavy water-permeability plastic film (patent number ZL201210390332.6) (Yang, Yao, Wei, \& Zhai, 2011; Yao, 1998; Yao, 2000; Yao, Wang, \& Yin, 1998; Yao \& Yin, 1999; Yao, Yin, \& Yang, 2000) with the film planter of 2MB-1/4 type used. The improvements of this new technique are the following: firstly, tow rows of shallow grooves are both dug separately inside and outside wheels of a tractor according to suiTable soil moisture, then foxtail millet is seeded in the grooves; secondly, accurate quantities of seeding are controlled in use of the separating device of tiny seeds equipped with a tube on barbs (patent number 
ZL201210213324.4), and four rows of seeding grooves and three rows of ridges are all covered with wide water-permeability plastic film (patent number ZL98119892.9); thirdly, three rows of ridges under water-permeability plastic film are made of roll marks of two tractor tyres and the trajectory mark of a geotome, from which three concave grooves of rain collection can come into being, and rain can permeate into soil through water-permeability plastic film on concave grooves; finally as we all know the moisture phenomenon of a thermos mouth, moisture will appear around seedling holes where film is punched and foxtail millet is seeded after raining, so compaction ratios of soil around seedling holes can be reduced and emergence ratios of millet seedlings will be improved. Consequently, in order that the important mechanism of high outputs about foxtail millet is discovered, which can provide the important theoretical basis for cultivations of high outputs of dry lands, contrastive experiments are carried out about seeding techniques between water-permeability plastic film and ordinary plastic film (Yang, He, Dong, Ren, \& Zhang, 2010), then the comparative relation of improving outputs of foxtail millet with ameliorating ecologic environments (Fan, Song, \& Yao, 2006; Yuan \& Hao, 2006) of dry lands is analyzed deeply.

\section{Materials and Methods}

\subsection{Materials}

Test materials included the following: seeds named Zhangza Millet 6, $1650 \mathrm{~mm}$ wide and $0.006 \mathrm{~mm}$ thick water-permeability plastic film, $800 \mathrm{~mm}$ wide and $0.006 \mathrm{~mm}$ thick ordinary plastic film, special fertilizer and farmhouse manure for foxtail millet, the accurate film planter of 2MB-1/4 type, the film planter of $2 \mathrm{MB}-1 / 2$ type, the small four-wheel tractor named Changzheng 250.

\subsection{Methods}

The test place was chosen in the dry flat area of sandy loam of HongAiZi village in Shenchi County of Shanxi Province, whose characters were $39^{\circ} 30^{\prime} \mathrm{N}$ and $1400 \mathrm{~m}$ altitude for the situation, $125 \mathrm{~d}$ for the frost-free period, $2800 \mathrm{~h}$ for the annual sunshine duration and $450 \mathrm{~mm}$ for the annual precipitation, meanwhile test time was arranged before the rainy season of 2012 and after the rainy season of 2013. Then there were six zones in the test place, each zone was $50 \mathrm{~m}$ long and $10 \mathrm{~m}$ wide, and two adjacent zones made up of a group of contrastive seeding experiments. $60 \mathrm{~kg}$ special fertilizer and $5000 \mathrm{~kg}$ farmhouse manure were used in each zone, and plans including technique mode I and technique mode $\Pi$ were carried out in two adjacent zones in order. Finally indexes were measured including outputs of foxtail millet, cumulative soil temperatures, soil moisture contents, soil nutrients, soil microbes, growth statuses of foxtail millet, LAI of foxtail millet, emergence ratios of millet seedlings, numbers of mature ears of millet seedlings and so on.

Technique mode I included the following: $1650 \mathrm{~mm}$ wide water-permeability plastic film, the planter of 2MB-1/4 type and the technique of seeding in accurate grooves and holes under wavy water-permeability plastic film; six planting bands in each zone, four rows of seeding grooves in each planting band, the row space of 43 $\mathrm{cm}$, the hole space of $28 \mathrm{~cm}, 8.3$ holes per square meter, 83000 holes per hectare, and 20 to 22 seeds named Zhangza Millet 6 in each hole.

Technique mode $\Pi$ included the following: $800 \mathrm{~mm}$ wide ordinary plastic film, the planter of 2MB-1/2 type and the technique of seeding in holes under ordinary plastic film; ten planting bands in each zone, second rows of seeding grooves in each planting band, the row space of $50 \mathrm{~cm}$, the hole space of $24 \mathrm{~cm}, 8.3$ holes per square meter, 83000 holes per hectare, and 20 to 22 seeds named Zhangza Millet 6 in each hole.

Figure 1 is the picture about Technique mode I.

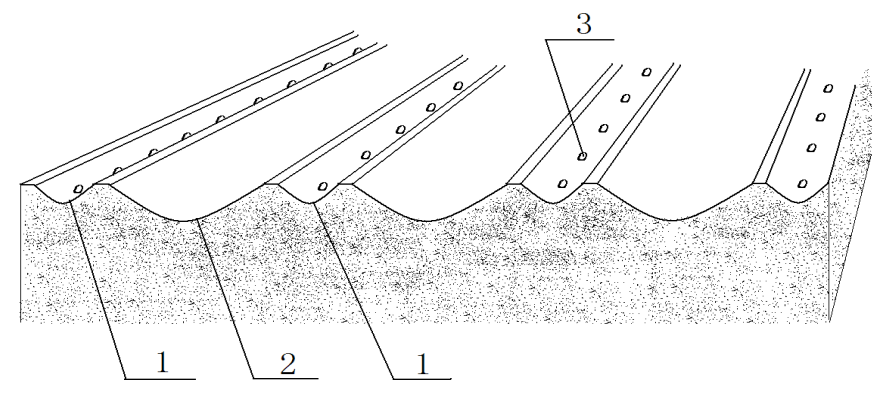

Figure 1. Seeding mode of technique I

Note. 1-Seeding grooves, 2-Rain ditches between seeding grooves, 3-Seeding holes. 


\section{Results}

Results from outputs of technique mode I and technique mode $\Pi$ in 2012 and 2013 among contrastive experiments are shown Table 1 and Table 2.

Table 1. Outputs of millet contrastive experiments in HongAiZi village of Shanxi Province in 2012

\begin{tabular}{|c|c|c|c|c|c|c|c|}
\hline \multirow{2}{*}{ Test type } & \multirow{2}{*}{ Technique modes } & \multicolumn{3}{|c|}{ Outputs per group $\left(\mathrm{kg} \cdot 500 \mathrm{~m}^{-2}\right)$} & \multirow{2}{*}{$\begin{array}{l}\text { Average outputs } \\
\left(\mathrm{kg} \cdot 500 \mathrm{~m}^{-2}\right)\end{array}$} & \multirow{2}{*}{$\begin{array}{l}\text { Output addition } \\
\left(\mathrm{kg} \cdot 500 \mathrm{~m}^{-2}\right)\end{array}$} & \multirow{2}{*}{$\begin{array}{l}\text { Output additional percentage } \\
\qquad(\%)\end{array}$} \\
\hline & & Group I & Group П & Group Ш & & & \\
\hline \multirow{6}{*}{ Zhangza Millet 6} & Technique mode I & 431.48 & 454.50 & 440.07 & 442.02 & \multirow{6}{*}{239.67} & \multirow{6}{*}{118.44} \\
\hline & Technique mode $\Pi$ & 192.36 & 210.20 & 204.49 & 202.35 & & \\
\hline & Additional percentages (\%) & 124.31 & 116.22 & 115.20 & & & \\
\hline & Averages & 311.92 & 332.35 & 322.28 & & & \\
\hline & Standard deviations & 169.08 & 172.75 & 166.58 & & & \\
\hline & Variation coefficients & 0.5421 & 0.5198 & 0.5169 & & & \\
\hline
\end{tabular}

Note. Group I includes zone 1 and zone 2, Group $\Pi$ includes zone 3 and zone 4, Group Ш includes zone 5 and zone 6.

Table 2. Outputs of millet contrastive experiments in HongAiZi village of Shanxi Province in 2013

\begin{tabular}{|c|c|c|c|c|c|c|c|}
\hline \multirow{2}{*}{ Test type } & \multirow{2}{*}{ Technique modes } & \multicolumn{3}{|c|}{ Outputs per group $\left(\mathrm{kg} \cdot 500 \mathrm{~m}^{-2}\right)$} & \multirow{2}{*}{$\begin{array}{c}\text { Average outputs } \\
\left(\mathrm{kg} \cdot 500 \mathrm{~m}^{-2}\right)\end{array}$} & \multirow{2}{*}{$\begin{array}{c}\text { Output addition } \\
\left(\mathrm{kg} \cdot 500 \mathrm{~m}^{-2}\right)\end{array}$} & \multirow{2}{*}{$\begin{array}{l}\text { Output additional } \\
\text { percentage }(\%)\end{array}$} \\
\hline & & Group I & Group П & Group Ш & & & \\
\hline \multirow{6}{*}{ Zhangza Millet 6} & Technique mode I & 480.21 & 483.18 & 498.37 & 487.25 & \multirow{6}{*}{245.13} & \multirow{6}{*}{101.24} \\
\hline & Technique mode $\Pi$ & 234.53 & 241.20 & 250.63 & 242.12 & & \\
\hline & Additional percentages (\%) & 104.75 & 100.32 & 98.85 & & & \\
\hline & Averages & 357.37 & 362.19 & 374.50 & & & \\
\hline & Standard deviations & 173.72 & 171.11 & 175.18 & & & \\
\hline & Variation coefficients & 0.4861 & 0.4724 & 0.4678 & & & \\
\hline
\end{tabular}

Note. Group I includes zone 1 and zone 2, Group $\Pi$ includes zone 3 and zone 4, Group Ш includes zone 5 and zone 6.

Statistical data in Table 1 and Table 2 show the following: variation coefficients of all groups about outputs between technique mode I and technique mode $\Pi$ are high and reach the most significant standard of chi-square test (Fan, Song, \& Hao, 2005), which shows that the output of technique mode I is higher than that of technique mode $\Pi$ evidently. Meanwhile the output additional percentage is up from $115.20 \%$ to $124.31 \%$ between technique mode I and technique mode $\Pi$ in 2012 , and the output additional percentage is up from $98.85 \%$ to $104.75 \%$ in 2013.

Therefore, on the basis of these results, the output of technique mode I is higher than the output of technique mode $\Pi$.

\section{Discussion}

\subsection{Analysis of Reasons About Increased Output}

Physical, chemical and biological factors can increase millet outputs (Xu, An, \& Hao, 2010; Zhang \& Yin, 2002). These factors include cumulative soil temperatures, soil moisture productivities and utilization ratios, fertilizer utilization ratios, microbial environments, and they provide superior conditions about temperatures, moisture, nutrients and microbes. Some exterior physiological features such as rapid seedlings growths, rational millet group structures, high seedlings emergence ratios and high numbers of seedlings mature ears can increase millet outputs. 


\subsubsection{Higher Cumulative Soil Temperature of Technique Mode I Than Technique Mode П}

During the seedling period of 2012 instantaneous soil temperatures (Cui, Guo, Hao, Du, \& Yan, 2008) of two technique modes were measured between four rows of seeding grooves according to four average interval depths $(\mathrm{d}=5 \mathrm{~cm})$ in planting layers of soil $(\mathrm{D}=20 \mathrm{~cm})$, which were $0-5 \mathrm{~cm}, 5-10 \mathrm{~cm}, 10-15 \mathrm{~cm}$ and $15-20 \mathrm{~cm}$, where thermometers were inserted and averages of 3 temperature data measured repeatedly were recorded, at the same time surface scopes were designed for one interval width $(\mathrm{W}=50 \mathrm{~cm})$. Specific circumstances about measuring soil temperatures of technique mode I were the following: in a planting band soil temperatures named $T_{1}, T_{2}$ and $\mathrm{T}_{3}$ were measured where three rows of ridges under plastic film were, at the same time the soil temperature named $\mathrm{T}_{4}$ was measured where one row of ridge without plastic film was; meanwhile the width of a planting band named $L_{1}$ was $172 \mathrm{~cm}$, the plastic film width of which always in sunshine was $129 \mathrm{~cm}$, then the row space named $r_{1}$ was $43 \mathrm{~cm}$, and the width without plastic film was also $43 \mathrm{~cm}$. Specific circumstances about measuring soil temperatures of technique mode $\Pi$ were the following: in two planting bands soil temperatures named $\mathrm{T}^{\prime}{ }_{1}$ and $\mathrm{T}_{3}^{\prime}$ were measured where two rows of ridges under plastic film were, at the same time soil temperatures named $\mathrm{T}^{\prime}{ }_{2}$ and $\mathrm{T}^{\prime}{ }_{4}$ were measured where two rows of ridges without plastic film were; meanwhile the width of two planting bands named $\mathrm{L}_{2}$ was $200 \mathrm{~cm}$, the plastic film width of which always in sunshine was $100 \mathrm{~cm}$, then the row space named $r_{2}$ was $50 \mathrm{~cm}$, and the width without plastic film was $100 \mathrm{~cm}$. So results of instantaneous soil temperatures are in Table 3.

Table 3. Instantaneous soil temperatures of millet contrastive experiments in HongAiZi village of Shanxi Province in 2012

\begin{tabular}{lllllllllll}
\hline \multirow{2}{*}{$\begin{array}{l}\text { Soil Interval depths } \\
\left(\mathrm{d}_{\mathrm{j}}\right)\end{array}$} & \multicolumn{8}{c}{ Soil temperatures of technique mode $\mathrm{I}\left({ }^{\circ} \mathrm{C} \cdot \mathrm{cm}^{-3}\right)$} & \multicolumn{6}{c}{ Soil temperatures of technique mode $\Pi\left({ }^{\circ} \mathrm{C} \cdot \mathrm{cm}^{-3}\right)$} \\
\cline { 2 - 12 } & $\mathrm{r}_{1}(\mathrm{~cm})$ & $\mathrm{T}_{1}$ & $\mathrm{~T}_{2}$ & $\mathrm{~T}_{3}$ & $\mathrm{~T}_{4}$ & $\mathrm{r}_{2}(\mathrm{~cm})$ & $\mathrm{T}_{1}{ }_{1}$ & $\mathrm{~T}_{2}^{\prime}$ & $\mathrm{T}_{3}^{\prime}$ & $\mathrm{T}_{4}$ \\
\hline $0-5 \mathrm{~cm}$ & 43 & 32.00 & 33.50 & 32.50 & 31.30 & 50 & 34.20 & 31.40 & 34.20 & 31.50 \\
$5-10 \mathrm{~cm}$ & 43 & 28.00 & 29.80 & 28.50 & 23.90 & 50 & 30.00 & 23.20 & 30.10 & 23.30 \\
$10-15 \mathrm{~cm}$ & 43 & 26.10 & 26.60 & 26.00 & 21.00 & 50 & 26.00 & 20.40 & 26.00 & 20.30 \\
$15-20 \mathrm{~cm}$ & 43 & 23.10 & 24.80 & 23.00 & 19.10 & 50 & 22.20 & 18.30 & 22.00 & 18.40 \\
\hline
\end{tabular}

The cumulative soil temperature (Yao, 2000) is the average temperature of instantaneous soil temperatures in the space of a certain length, width and depth. Next its mathematical model is the following formula:

$$
\mathrm{ST}=\left(\sum \sum \mathrm{w}_{\mathrm{i}} \cdot \mathrm{d}_{\mathrm{j}} \cdot \mathrm{r}_{\mathrm{k}} \cdot \mathrm{T}_{\mathrm{ijk}}\right) /(\mathrm{W} \cdot \mathrm{D} \cdot \mathrm{L})
$$

ST means cumulative soil temperatures, $w_{i}$ means interval widths about soil test units, $d_{j}$ means interval depths about test units, $r_{k}$ means interval lengths about test units, $T_{\mathrm{ijk}}$ means instantaneous soil temperatures, $\mathrm{W}$ means the total width of test units, D means the total depth of test units, and $\mathrm{L}$ means the total length of test units, at the same time the digital circumstances of test units are the following numbers: $i=1 ; j=1,2,3,4 ; k=1,2,3,4$.

In connection with cumulative soil temperatures of technique mode I and technique mode $\Pi$, parameters named $\mathrm{W}_{\mathrm{i}}$ and $\mathrm{W}$ in ST were both designed for $50 \mathrm{~cm}$, then other parameters in ST are in Table 3 and the first paragraph of section 2.1 separately. So according to all parameters results are gotten including $\mathrm{ST}_{1}=26.83^{\circ} \mathrm{C} \cdot \mathrm{cm}^{-3}$ and $\mathrm{ST}_{2}=25.72^{\circ} \mathrm{C} \cdot \mathrm{cm}^{-3}$, which show the cumulative soil temperature of technique mode I is $1.11^{\circ} \mathrm{C} \cdot \mathrm{cm}^{-3}$ higher than that of technique mode $\Pi$ because the percentage of mulching plastic film about technique mode I is bigger that provided better soil temperature in order to improve millet outputs efficiently.

\subsubsection{Higher Soil Moisture Productivity and Utilization Ratio of Technique Mode I Than Technique Mode П}

On the basis of soil bulk densities and soil moisture percentages in depths of 0-100 cm measured before planting and after harvesting in 2012, soil moisture contents of technique mode I and technique mode $\Pi$ are calculated and results are in Table 4; next on the basis of rainfall of the growth period for $396 \mathrm{~mm}$ from the local weather station between May 6th and September 23rd, soil moisture productivities and utilization ratios of technique mode $I$ and technique mode $\Pi$ are calculated in connection with the water consumption coefficient of outputs of foxtail millet for 450 (Yang, Yang, Xue, Shang, \& Han, 2011), results of which are in Table 5. 
Table 4. Soil moisture circumstances of millet contrastive experiments in HongAiZi village of Shanxi Province in 2012

\begin{tabular}{|c|c|c|c|c|c|c|c|}
\hline \multirow{3}{*}{$\begin{array}{c}\text { Sampling } \\
\text { depths }(\mathrm{cm})\end{array}$} & \multirow{3}{*}{$\begin{array}{c}\text { Soil bulk } \\
\text { densities } \\
\left(\mathrm{g} \cdot \mathrm{cm}^{-3}\right)\end{array}$} & \multicolumn{2}{|c|}{ Planting period before May 6th } & \multicolumn{4}{|c|}{ Harvesting period after September 23rd } \\
\hline & & \multirow{2}{*}{$\begin{array}{c}\text { Moisture } \\
\text { percentages }(\%)\end{array}$} & \multirow{2}{*}{$\begin{array}{c}\text { Moisture } \\
\text { contents }(\mathrm{mm})\end{array}$} & \multicolumn{2}{|c|}{ Technique mode I } & \multicolumn{2}{|c|}{ Technique mode $\Pi$} \\
\hline & & & & $\begin{array}{c}\text { Moisture } \\
\text { percentages (\%) }\end{array}$ & $\begin{array}{c}\text { Moisture } \\
\text { contents (mm) }\end{array}$ & $\begin{array}{c}\text { Moisture } \\
\text { percentages (\%) }\end{array}$ & $\begin{array}{c}\text { Moisture } \\
\text { contents }(\mathrm{mm})\end{array}$ \\
\hline $0-20 \mathrm{~cm}$ & 1.11 & 18.60 & 20.65 & 15.50 & 17.21 & 14.20 & 15.76 \\
\hline $20-40 \mathrm{~cm}$ & 1.14 & 15.50 & 17.67 & 14.30 & 16.30 & 13.40 & 15.28 \\
\hline $40-60 \mathrm{~cm}$ & 1.15 & 14.40 & 16.56 & 13.50 & 15.53 & 13.30 & 15.30 \\
\hline $60-80 \mathrm{~cm}$ & 1.17 & 13.30 & 15.56 & 13.40 & 15.68 & 13.10 & 15.33 \\
\hline $80-100 \mathrm{~cm}$ & 1.18 & 13.20 & 15.58 & 13.30 & 15.69 & 13.00 & 15.34 \\
\hline
\end{tabular}

Note. Moisture content $=$ Bulk density $\times$ Moisture percentage.

Table 5. Circumstances of soil moisture utilization ratios between $0 \mathrm{~cm}$ and $100 \mathrm{~cm}$ in HongAiZi village of Shanxi Province in 2012

\begin{tabular}{lccc}
\hline Indexes & & Technique mode I & Technique mode $\Pi$ \\
\hline Soil moisture contents before planting $(\mathrm{mm})$ & $(1)$ & 86.01 & 86.01 \\
Soil moisture contents after harvesting $(\mathrm{mm})$ & $(2)$ & 80.40 & 77.00 \\
Rainfall in growth period $(\mathrm{mm})$ & $(3)$ & 396.00 & 396.00 \\
Water consumptions in growth period $(\mathrm{mm})$ & $(4)$ & 401.60 & 405.00 \\
Millet outputs per Square hectares $\left(\mathrm{kg} \cdot \mathrm{hm}^{-2}\right)$ & $(5)$ & 8840.33 & 4047.00 \\
Water supplements per Square hectares $\left(\mathrm{kg} \cdot \mathrm{hm}^{-2}\right)$ & $(6)$ & 10711.11 & 10711.11 \\
Soil moisture productivities $\left(\mathrm{kg} \cdot \mathrm{mm}^{-1} \cdot \mathrm{hm}^{-2}\right)$ & $(7)$ & 22.01 & 9.99 \\
Soil moisture utilization ratios $(\%)$ & $(8)$ & 82.53 & 37.78 \\
\hline
\end{tabular}

Note. (1) and (2) corresponding refer to total moisture contents of the total depth from Table 4, (5) refers to the transformation result of average outputs from Table 1, (4) $=(3)+(1)-(2),(6)=10000 \times\{(3)+(1)\} / 450,(7)=(5) /(4)$, $(8)=(5) /(6)$.

According to data in Table 5 the soil moisture productivity and utilization ratio of technique mode I in depths of $0-100 \mathrm{~cm}$ are $22.01 \%$ and $82.53 \%$ separately while those of technique mode $\Pi$ are $9.99 \%$ and $37.78 \%$ higher, so it shows conditions of moisture utilization for technique mode I are better than those for technique mode $\Pi$ because the rainfall resource is utilized efficiently (Yao \& Yin, 1999; Yao, 2000; Yao et al., 2000) in use of technique mode I in order to provide superior moisture conditions for improving millet outputs efficiently.

\subsubsection{Higher Fertilizer Utilization Ratio of Technique Mode I Than Technique Mode П}

Respective average contents of four soil nutrients including available $\mathrm{N}$, available $\mathrm{P}$, available $\mathrm{K}$ and organic matter were measured in depths of $0-20 \mathrm{~cm}$ of planting layers in soil test units before planting of 2012, then results were gotten including $\mathrm{N}$ for $0.65 \mathrm{mg} \cdot \mathrm{kg}^{-1}, \mathrm{P}_{2} \mathrm{O}_{5}$ for $9.65 \mathrm{mg} \cdot \mathrm{kg}^{-1}, \mathrm{~K}_{2} \mathrm{O}$ for $115 \mathrm{mg} \cdot \mathrm{kg}^{-1}$ and organic matter for $11.00 \mathrm{~g}^{\mathrm{kg}} \mathrm{g}^{-1}$; by contrast, average contents of four soil nutrients were measured repeatedly after harvesting of 2012 , then contents of technique mode $\mathrm{I}$ were $\mathrm{N}$ for $51.60 \mathrm{mg} \cdot \mathrm{kg}^{-1}, \mathrm{P}_{2} \mathrm{O}_{5}$ for $10.30 \mathrm{mg} \cdot \mathrm{kg}^{-1}, \mathrm{~K}_{2} \mathrm{O}$ for $101.80 \mathrm{mg} \cdot \mathrm{kg}^{-1}$ and organic matter for $9.26 \mathrm{~g} \cdot \mathrm{kg}^{-1}$, and those of technique mode $\Pi$ were $\mathrm{N}$ for $71.50 \mathrm{mg} \cdot \mathrm{kg}^{-1}, \mathrm{P}_{2} \mathrm{O}_{5}$ for $12.60 \mathrm{mg} \cdot \mathrm{kg}^{-1}, \mathrm{~K}_{2} \mathrm{O}$ for $115.50 \mathrm{mg} \cdot \mathrm{kg}^{-1}$ and organic matter for $10.53 \mathrm{~g} \cdot \mathrm{kg}^{-1}$.

Foregoing results about $\mathrm{N}, \mathrm{P}, \mathrm{K}$ and organic matter make it clear that the fertilizer utilization ratio of technique mode I is higher, which is one of important reasons about improving millet outputs obviously, because conversion ratios of $\mathrm{N}, \mathrm{P}, \mathrm{K}$ and organic matter about technique mode I are respectively increased for $27.8 \%$, $18.3 \%, 11.9 \%$ and $12.1 \%$ more than those about technique mode $\Pi$ although there are the same original soil nutrients and fertilizer about technique mode I and technique mode $\Pi$. 
Soil in depths of 0-20 $\mathrm{cm}$ of technique mode I and technique mode $\Pi$ was sampled in test units before harvesting of 2012, then live microbe categories and their densities in soil were measured by culture medium method, results about which are in Table 6.

Table 6. Soil microbe categories and densities in depths of 0-20 cm about two modes of mulching film

\begin{tabular}{llcc}
\hline \multicolumn{1}{l}{ Soil microbe categories } & Technique mode I & Technique mode $\Pi$ \\
\hline Live bacteria & Categories & $\begin{array}{c}\text { Gas bacillus, Escherichia coli, } \\
\text { Bacillus, Pseudomonas }\end{array}$ & $\begin{array}{c}\text { Escherichia coli, Bacillus, } \\
\text { Pseudomonas }\end{array}$ \\
& Densities (numbers $\cdot 100 \mathrm{~g}^{-1}$ soil) & $1.67 \times 10^{6}$ & $2.20 \times 10^{6}$ \\
Live yeasts & Categories & Yeast & Candida \\
& Densities (numbers $100 \mathrm{~g}^{-1}$ soil) & $3.33 \times 10^{4}$ & $1.67 \times 10^{4}$ \\
Live actinomyces & Densities (numbers $100 \mathrm{~g}^{-1}$ soil) & $2.50 \times 10^{7}$ & $2.56 \times 10^{6}$ \\
Live moulds & Categories & - & Aspergillus \\
& Densities (numbers $\cdot 100 \mathrm{~g}^{-1}$ soil) & 0 & $3.33 \times 10^{4}$ \\
Total live microbes & Densities (numbers $\cdot 100 \mathrm{~g}^{-1}$ soil) & $2.67 \times 10^{7}$ & $4.81 \times 10^{6}$ \\
\hline
\end{tabular}

According to data in Table 6 there are Gas bacillus and Yeast about technique mode I, in contrast, there are not those about technique mode $\Pi$, however, Candida and Aspergillus are increased; meanwhile densities of total live microbes of technique mode I are 5.55 times more than those of technique mode $\Pi$, especially densities of live actinomyces among which are 9.77 times more. As a result it shows that it is more efficient for technique mode I to improve millet outputs because more superior microbial environments are provided that benefits from activities of aerobic microbes in use of technique mode I.

\subsubsection{More Rapid Growth of Millet Seedlings of Technique Mode I Than Technique Mode $\Pi$}

Growth indexes of foxtail millet such as leaf numbers and strains heights were investigated or measured during certain periods of 2012 and 2013, which were before harvesting and twenty days after seeding, then results about growth indexes are in Table 7.

Table 7. Millet growth statuses of different technique modes in 2012 and 2013

\begin{tabular}{|c|c|c|c|c|c|c|c|}
\hline Time & Technique modes & Leaf numbers & $\begin{array}{l}\text { Strains heights } \\
(\mathrm{cm})\end{array}$ & $\begin{array}{c}\text { Stem thicknesses } \\
(\mathrm{mm})\end{array}$ & $\begin{array}{c}\text { Roots } \\
\text { (numbers) }\end{array}$ & $\begin{array}{c}\text { Average } \\
\text { ear numbers }\end{array}$ & $\begin{array}{l}\text { Dry weights } \\
\text { per plant }(\mathrm{g})\end{array}$ \\
\hline \multirow[t]{2}{*}{ May 31 st in 2012} & Technique mode I & 6 leaves and 1 core & 14.50 & 3.50 & 7.00 & & \\
\hline & Technique mode $\Pi$ & 5 leaves and 1 core & 6.50 & 2.40 & 4.00 & & \\
\hline \multirow[t]{2}{*}{ August 1st in 2012} & Technique mode I & 14 & 128.50 & 6.60 & 30.50 & 68.00 & 24.50 \\
\hline & Technique mode $\Pi$ & 11.50 & 112.00 & 6.00 & 28.50 & 65.50 & 18.40 \\
\hline \multirow[t]{2}{*}{ May 31st in 2012} & Technique mode I & 6 leaves and 1 core & 15.00 & 3.50 & 7.20 & & \\
\hline & Technique mode $\Pi$ & 5 leaves and 1 core & 6.80 & 2.40 & 4.10 & & \\
\hline \multirow[t]{2}{*}{ September 30th in 2013} & Technique mode I & 14 & 135.00 & 6.80 & 35.00 & 91.00 & 44.86 \\
\hline & Technique mode $\Pi$ & 13 & 129.00 & 6.20 & 28.80 & 66.00 & 37.25 \\
\hline
\end{tabular}

Continuous data of two yeas in Table 7 show that the growth of technique mode I is more rapid and millet seedlings are stronger than those of technique mode $\Pi$, which are visible exterior features about higher outputs of foxtail millet.

\subsubsection{Higher Millet LAI of Technique Mode I Than Technique Mode $\Pi$ in Different Periods}

After LAI was measured in seedling and blooming periods of 2012, it indicates that LAI of technique mode I correspondingly for 0.31 and 7.58 is higher than that of technique mode $\Pi$ correspondingly for 0.18 and 2.86 . Furthermore, after investigating in the period of the biggest leaf area, the following facts were found: there were even sunshine spots that only covered $5 \%-8 \%$ of soil on the ground between seeding holes about technique mode I, on the contrary there were dense sunshine spots that highly covered $25 \%-32 \%$ of soil about technique mode $\Pi$. Through analyzing LAI with the biggest leaf area together (Xu, An, \& Hao, 2007), it shows that technique mode I benefits to utilize solar energy more efficiently than technique mode $\Pi$ (Yao, 1998) so that leaves can grow 
better because rational group structures of foxtail millet can come into being in use of technique mode I, which are visible features about higher outputs of foxtail millet.

\subsubsection{Higher Emergence Ratio of Millet Seedlings of Technique Mode I Than Technique Mode $\Pi$}

Investigation results in the seedling period of 2012 were the following: the seedling period of technique mode I came two days in advance earlier than that of technique mode $\Pi$; then seeding hole ratios without millet seedlings of technique mode I were $14.84 \%$ obviously lower than those of technique mode $\Pi$, which were $30.00 \%$; finally average seedling numbers in each hole about technique mode I were 7.18 while those about technique mode $\Pi$ were 4.60 lower. Investigation results in the seedling period of 2013 were the following: the seedling period of technique mode I came one day in advance earlier than that of technique mode $\Pi$; then seeding hole ratios without millet seedlings of technique mode I were $15.20 \%$ obviously lower than those of technique mode $\Pi$, which were $35.00 \%$. As a result technique mode I can prominently improve seedling numbers in each hole and reduce seeding hole ratios without millet seedlings in contrast to technique mode $\Pi$.

Investigation results in the harvesting period of 2012 were the following: firstly, average mature ear numbers of millet seedlings in each seeding hole about technique mode I were 7.23 obviously higher than those about technique mode $\Pi$ that were 5.17; secondly, mature ear numbers of millet seedlings per square hectare about technique mode I were 494722 rising for $112.88 \%$ above those about technique mode $\Pi$ that were 232400 (Guo, Cui, Hao, \& Du, 2012); thirdly, average seed numbers of mature ears were 6382 rising for $0.79 \%$ above those about technique mode $\Pi$ that were 6332 ; fourthly, weights of 1000 seeds of technique mode I were $2.80 \mathrm{~g}$ increased for $1.82 \%$ above those of technique mode $\Pi$ that were $2.75 \mathrm{~g}$. Investigation results in the harvesting period of 2013 were the following: firstly, average mature ear numbers of millet seedlings in each seeding hole about technique mode I were 7.10 obviously higher than those about technique mode $\Pi$ that were 4.20 ; secondly, mature ear numbers of millet seedlings per square hectare about technique mode I were 493002 rising for $114.33 \%$ above those about technique mode $\Pi$ that were 230025 (Guo et al., 2012); thirdly, average seed numbers of mature ears were 7705 rising for $9.20 \%$ above those about technique mode $\Pi$ that were 7056 ; fourthly, weights of 1000 seeds of technique mode I were $2.95 \mathrm{~g}$ increased for $1.72 \%$ above those of technique mode $\Pi$ that were $2.90 \mathrm{~g}$. So investigation results in harvesting periods of 2012 and 2013 show that seed numbers and seed weights of technique mode I especially mature ear numbers are higher than those of technique mode $\Pi$. What's more, contribution ratios (Yao, 1987) of mature ear numbers, seed numbers and seed weights to millet outputs are respectively $97.74 \%, 0.68 \%$ and $1.75 \%$ according to test results of 2012 , at the same time those are respectively $97.74 \%, 0.78 \%$ and $1.47 \%$ according to test results of 2013 , both of which show that the contribution ratios of mature ear numbers to outputs are the biggest.

Table 8 is about results of emergence ratios of millet seedlings, mature ear numbers of millet seedlings and millet outputs in six test zones in 2012 and 2013.

Table 8. Emergence ratios of seedlings, mature ear numbers of seedlings and outputs in test zones

\begin{tabular}{|c|c|c|c|c|c|}
\hline Test time & Test zones & Test modes & $\begin{array}{c}\text { Average seedling } \\
\text { emergence ratios } \\
\text { per hole }(\%) \mathrm{x}\end{array}$ & $\begin{array}{l}\text { Average mature ear } \\
\text { numbers of seedlings } \\
\text { per hole(ears) } \mathrm{y}_{1}\end{array}$ & $\begin{array}{l}\text { Outputs per } \\
\text { zone }(\mathrm{kg}) \mathrm{y}_{2}\end{array}$ \\
\hline \multirow[t]{3}{*}{ The year of 2012} & Zone 1 & Technique mode I & 83.52 & 7.12 & 431.48 \\
\hline & Zone 3 & Technique mode I & 87.50 & 7.30 & 454.50 \\
\hline & Zone 5 & Technique mode I & 84.45 & 7.27 & 440.07 \\
\hline \multirow[t]{3}{*}{ The year of 2013} & Zone 1 & Technique mode I & 82.35 & 6.85 & 480.21 \\
\hline & Zone 3 & Technique mode I & 85.47 & 7.13 & 483.18 \\
\hline & Zone 5 & Technique mode I & 86.58 & 7.32 & 498.37 \\
\hline \multirow[t]{3}{*}{ The year of 2012} & Zone 2 & Technique mode $\Pi$ & 68.71 & 5.06 & 192.36 \\
\hline & Zone 4 & Technique mode $\Pi$ & 71.25 & 5.30 & 210.20 \\
\hline & Zone 6 & Technique mode $\Pi$ & 70.04 & 5.15 & 204.49 \\
\hline \multirow[t]{3}{*}{ The year of 2013} & Zone 2 & Technique mode $\Pi$ & 62.72 & 3.89 & 234.53 \\
\hline & Zone 4 & Technique mode $\Pi$ & 66.37 & 4.17 & 241.20 \\
\hline & Zone 6 & Technique mode $\Pi$ & 65.91 & 4.54 & 250.63 \\
\hline
\end{tabular}


Analytical results of Table 8 from statistical methods show that emergence ratios of millet seedlings and mature ear numbers of millet seedlings are significantly correlated to the level of $\alpha=0.05$ because the correlative coefficient between $\mathrm{x}$ and $\mathrm{y}_{1}$ is 0.9917 and there is $|t|=2.4476>\mathrm{t}_{0.05,10}(=2.2280)$; moreover, those show that emergence ratios of millet seedlings and millet outputs reach to the level of $\alpha=0.001$ more significantly because the correlative coefficient between $\mathrm{x}$ and $\mathrm{y}_{2}$ is 0.9343 and there is $|t|=8.2900>\mathrm{t}_{0.001,10}(=4.5870)$. Consequently $\mathrm{x}$ is in obvious relation with $\mathrm{y}_{1}$ and $\mathrm{y}_{2}$.

Above all, emergence ratios and mature ear numbers of millet seedlings about technique mode I are improved more significantly than those about technique mode $\Pi$, at the same time emergence ratios are significantly correlated to mature ear numbers and outputs, and the contribution ratio of mature ear numbers to outputs is the biggest, therefore millet outputs can be improved more efficiently in use of technique mode I.

\subsection{Contrastive Studies at Home and Abroad}

Studies of seeding foxtail millet under ordinary plastic film in dry lands date from the early period of 1990s (T. Yang et al., 2010), central techniques of which include flat plastic film and mounds plastic film (T. Yang et al., 2010), and it is an important measure without seedling thinning appearing in cold and dry areas, which is obviously significant for improving millet outputs. However, the effect of rain collection is poor and it is difficult for millet seedlings to grow (T. Yang et al., 2010) about flat plastic film, meanwhile effects of increasing soil temperatures and holding soil moisture about mounds plastic film are poorer than those about flat plastic film (T. Yang et al., 2010), so many problems appear including too big row spaces of millet seeding, low emergence ratios of millet seedlings, difficult controlling seeding quantities and so on. In order to solve technical defects of ordinary plastic film, the new technique was invented named seeding foxtail millet in accurate grooves and holes under wide and wavy water-permeability plastic film in this thesis. After contrastive experiments about technique mode I and technique mode $\Pi$ are carried out, it is certain that seeding hole ratios without millet seedlings can be reduced and emergence ratios of millet seedlings can be improved mainly because the film planter was optimally designed about the new technique named water-permeability plastic film. When the new film planter named 2MB-1/4 type is utilized in the farming field, mulching plastic film, punching in plastic film, seeding accurately, covering seedling holes with soil and compacting soil can all be finished automatically, at the same time rain can be converged in ditches between seeding grooves and permeate under plastic film in order to reduce hard soil around seedling holes after raining and seeding hole ratios without seedlings further, meanwhile moisture around seedling holes like the moisture phenomenon of a thermos mouth can make millet seedlings grow out of soil smoothly. Therefore in this thesis in connection with studies of seeding foxtail millet under ordinary plastic film in dry lands (T. Yang et al., 2010), on the one hand defects of their central techniques are analyzed, on the other hand the technique named seeding foxtail millet in accurate grooves and holes under wide and wavy water-permeability plastic film is a new technique about improving millet outputs millet and a sort of periodical fruit about techniques of cultivating foxtail millet.

\subsection{Revelations of This Study}

What's more, in this thesis the mechanism is explored about improving millet outputs in use of the technique named seeding foxtail millet in accurate grooves and holes under wide and wavy water-permeability plastic film, in the first place, physical, chemical and biological factors are analyzed about reasons of increased millet outputs, in the next place, exterior physiological features are summarized about increased millet outputs. Then the following important revelations are obtained about increased millet outputs: (1) soil temperature changes in conditions of mulching different plastic film can be described more objectively in use of the concept and method of cumulative soil temperatures; (2) utilization ratios of soil moisture resulting from water consumptions and supplements can disclose unexploited soil moisture potentiality for millet productions in dry lands of semiarid areas, which benefits more than $70 \%$ of rainfall resources to be utilized efficiently (Yao \& Yin, 1999); (3) dynamic differences of soil ecologic environments about both technique modes can be disclosed with $\mathrm{N}, \mathrm{P}, \mathrm{K}$, organic matter, microbial categories and densities measured; (4) different LAI in seedling and blooming periods and sunshine spots densities can reflect rational differences of group structures; (5) subtle physiological differences of two technique modes can be disclosed with growth dynamics, emergence ratios and mature ear numbers of millet seedlings investigated or measured, which shows that these physiological features are closely related to millet outputs.

\section{Conclusions}

In connection with problems of the technique named seeding foxtail millet in holes under ordinary plastic film including too big row spaces of seeding, low emergence ratios of seedlings, difficult controlling seeding quantities and so on, the technique is introduced named seeding foxtail millet in accurate grooves and holes 
under wide and wavy water-permeability plastic film in this thesis, then a important result is obtained which is the technique named water-permeability plastic film is more superior than that named ordinary plastic film on the basis of contrastive experiments, so millet outputs are improved efficiently because technical defects of ordinary plastic film can be solved in use of the technique named water-permeability plastic film; meanwhile two aspects of reasons of increased millet outputs are analyzed including physical, chemical, biological factors and exterior physiological features, then further some important revelations are explored about cumulative soil temperatures, soil moisture potentiality, soil ecologic environments, group structures of foxtail millet and so on. Finally as a result it is certain that seeding foxtail millet in accurate grooves and holes under wide and wavy water-permeability plastic film is an better ameliorative technique than seeding foxtail millet in holes under ordinary plastic film, therefore it is a fact that millet outputs are improved efficiently because ecologic environments in planting layers of soil are ameliorated in use of this technique named water-permeability plastic film and furthermore technical defects of ordinary plastic film are solved so that seeding qualities of foxtail millet are improved.

\section{Acknowledgements}

This thesis is financially supported by the ShanXi Science and Technology Department of China (20130311008-2) and the Shanxi Finance Department of China (2013216022).

\section{References}

Cui, F. Z., Guo, X. Q., Hao, J. P., Du, T. Q., \& Yan, X. B. (2008). Study on soil temperature variation of water-permeability plastic film mulching on dry land foxtail millet. J. SHANXI AGRIC UNIV., 28, 172-175. http://dx.doi.org/10.3969/j.issn.1671-8151.2008.02.016

Fan, J. H., Song, X. L., \& Hao, J. P. (2005). Studies on two effects of water-permeability plastic membrane mulching in rainfed wheat field. Journal of Liaoning Agricultural College, 7, 1-5. http://dx.doi.org/10.3969/j.issn.1671-0517.2005.04.001

Fan, J. H., Song, X. L., \& Yao, J. Z. (2006). Studies on ecological effect of water-permeability plastic membrane mulching in winter wheat field. Journal of Tianjin Agricultral University, 13, 32-35. http://dx.doi.org/10.3969/j.issn.1008-5394.2006.02.008

Gu, S. L., Ma, J. P., Gu, Z. M., Du, J. E., \& Sun, C. Q. (2004). The origin and primary development of millet cultivation in Shanxi. Journal of Shanxi Agricultural Sciences, 32, $24-28$. http://dx.doi.org/10.3969/j.issn.1002-2481.2004.04.006

Guo, X. Q., Cui, F. Z., Hao, J. P., \& Du, T. Q. (2012). Growth stage and yield of dry land foxtail millet (setaria italica) under water-permeability plastic film mulching. J. SHANXI AGRIC. UNIV., 32, 107-111. http://dx.doi.org/10.3969/j.issn.1671-8151.2012.02.003

Guo, Z. L., \& Gu, S. L. (2000). Effect of film-mulching cultivation methods on yield and economic efficiency of millet. Agricultural Research in the Arid Areas, 18, 33-39. http://dx.doi.org/ 10.3321/j.issn:1000-7601.2000.02.006

Jiang, J., Wang, J. P., \& Jia, Z. K. (1999). Experiment report on dry land millet cultivation with film mulching and hole seeding in southern Ningxia. Agricultural Research in the Arid Areas, 17, 31-36. http://dx.doi.org/10.3321/j.issn:1000-7601.1999.02.006

Joshi, B. N., Sainani, M. N., Bastawade, K. B., \& Gupta, V. S. (1998). Cysteine protease inhibitor from pearl millet: a new class of antifungal protein. Biochemical and Biophysical Research Communications, 246, 382-387. http://dx.doi.org/10.1006/bbrc.1998.8625

Ma, J. P., Wang, Z., \& Wang, Y. L. (1998). Present situation and prospect of millet production in Shanxi province. Rain Fed Crops, 18, 32-34.

Ravindran, G. (1991). Studies on millet proximate composition, mineral composition and phytate and oxalate contents. Food Chemistry, 39, 99-107. http://dx.doi.org/10.1016/0308-8146(91)90088-6

Tian, G., Wang, Y. W., Li, H. X., Liu, Z. H., \& Liu, X. (2013). Current situation and development measures for millet industry in Shanxi province. Journal of Shanxi Agricultural Sciences, 41, 299-300, 306. http://dx.doi.org/10.3969/j.issn.1002-2481.2013.03.25

$\mathrm{Xu}$, L., An, W., \& Hao, J. P. (2010). The effect of water-osmosis plastic membrane on physiology, yield component and yield for drought maize. Journal of Arid Land Resources and Environment, 24, 180-185. 
Xu, L., An, W., \& Hao, J. P. (2007). Effect of water-osmosis plastic membrane on maize growth. Journal of Maize Sciences, 15, 119-122. http://dx.doi.org/10.3969/j.issn.1005-0906.2007.04.031

Yang, C., Tian, Z. F., Lu, J. M., Yang, X. L., \& Ding, W. Y. (2010). Research progress on millet protein. Journal of the Chinese Cereals and Oils Association, 25, 123-128.

Yang, H. M., Shi, L., \& Wang, J. G. (2006). Approach to millet production and its industrialization in Shanxi. Journal of Shanxi Agricultural Sciences, 34, 11-13. http://dx.doi.org/10.3969/j.issn.1002- 2481.2006.04.003

Yang, R. P., Yao, J. M., Wei, Y. C., \& Zhai, Y. Y. (2011). Model of water permeable plastic film high productivity cultivation technology in multi-V mulching. Journal of Shanxi Agricultural Sciences, 39, 140-143. http://dx.doi.org/10.3969/j.issn.1002-2481.2011.02.13

Yang, T. Y., He, J. H., Dong, K. J., Ren, R. Y., \& Zhang, L. (2010). Studies and applications of mulching film cultivation on foxtail millet in dry areas. Chinese Agricultural Science Bulletin, 26, 86-90.

Yang, Z. P., Yang, Z. J., Xue, Y. F., Shang, H. F., \& Han, W. F. (2011). Study on water consumption of winter wheat and summer millet using undisturbed soil columns under different precipitation years. Journal of Henan Agricultural Sciences, 40, 58-61. http://dx.doi.org/10.3969/j.issn.1004-3268. 2011.09.017

Yao, J. M. (1987). Analysis on the relations between the constituents and levels of the yield of wheat in the basin in the south of Shanxi. Acta Agroci;tirae Bpreali-Sinica, 2, 43-47.

Yao, J. M. (1998). Studies on water-osmotic film and dry-land farming. Journal of Natural Resources, 13, 368-370. http://dx.doi.org/10.3321/j.issn.1000-3037.1998.04.013

Yao, J. M. (2000). The invention and application of water-permeability plastic membrane. Acta Agronomica Sinica, 26, 185-189. http://dx.doi.org/10.3321/j.issn.0496-3490.2000.02.009

Yao, J. M., \& Yin, H. S. (1999). Rainfall resources validation and dryland farming. Resources Science, 21, 47-50. http://dx.doi.org/10.3321/j.issn.1007-7588.1999.04.011

Yao, J. M., Wang, H. C., \& Yin, H. S. (1998). A test of winter wheat bunch sowing with water-osmosis plastic membrane covering in semi-arid land. Journal of Shanxi Agricultural Sciences, 26, 7-10.

Yao, J. M., Yin, H. S., \& Yang, R. P. (2000). Study on small rain utilization technique by water-permeability plastic film covering. Research of Soil and Water Conservation, 7, 36-38. http://dx.doi.org/10.3969/j.issn.1005-3409.2000.04.007

Yuan, H. J., \& Hao, J. P. (2006). Studies of ecological and yield effect of water-osmosis plastic membrane in rainfed cotton field. Chinese Agricultural Science Bulletin, 22, 442-447. http://dx.doi.org/10.3969/j.issn.1000-6850.2006.05.112

Zhang, Q. F., \& Yin, H. S. (2002). The effects of water-permeability plastic film mulching on soil water, soil temperature and maize yield. Chinese Journal of Agrometeorology, 23, 46-48. http://dx.doi.org/10.3969/j.issn.1000-6362.2002.03.012

Zhao, R. H., Huang, M. J., \& Li, P. (1998). Effects of mulch and ridge plant on dryland millet field at fallow stage. Eco-Agriculture Research, 6, 30-32.

Zhu, Y., Chen, Y. Q., \& Ren, Y. M. (1998). A cultural test on film mulching of foxtail millet. Journal of Shanxi Agricultural Sciences, 26, 15-17.

\section{Copyrights}

Copyright for this article is retained by the author(s), with first publication rights granted to the journal.

This is an open-access article distributed under the terms and conditions of the Creative Commons Attribution license (http://creativecommons.org/licenses/by/3.0/). 